\title{
Introduction
}

\begin{abstract}
To what extent and how does independent hip-hop challenge or reproduce US mainstream hip-hop culture and US culture more generally? This chapter attempts to address this age-old question. The author also reviews the history and literature on hip-hop culture, provides an overview of the underlying theory and methodology, and gives an outline of the remaining chapters. His research combines neo-Marxist, critical race, intersectional feminist, and queer theories, as well as Mansbridge and Morris' (Oppositional Consciousness: The Subjective Roots of Social Protest, University of Chicago Press, Chicago, 2001) concept of oppositional consciousness. The research design utilizes a mixed methods approach, which includes content analysis of twenty-five indie albums from 2000 to 2013 and interviews with forty-six members of the independent hip-hop community, to uncover the historical trajectory of independent hip-hop in the post-golden era and how it has affected the culture today.
\end{abstract}

Keywords Independent hip-hop - Mainstream hip-hop • Post-golden era - Race and class - Gender and sexuality • Oppositional consciousness

Hip-hop, or the cultural movement that developed during the late 1970s, and hip-hop music (aka rap music), or the aspect of hip-hop that focuses on the musical style where rhyming speech is done to the beat of

(C) The Author(s) 2019

C. Vito, The Values of Independent Hip-Hop in the Post-Golden Era, https://doi.org/10.1007/978-3-030-02481-9_1 
music (Davey D 1984), have always faced a pull between "commercial vitality and its strivings to be a meaningful source of youth empowerment and social change" (Watkins 2005: 10). With the rise in popularity of hip-hop in the 1990s, large corporations began to invest in the culture and actively recruited musicians who fit the persona of a "gangster" to sell records. By 1998, hip-hop reached an impasse wherein sales reached its peak but also saw a majority of record sales under the creative control of major companies. More importantly, Watkins argues the pull between the two competing factors seemed to be swaying toward commercial vitality. As a response indie labels began to grow as there was push-back from artists and listeners who were concerned with the shift in the content of mainstream hip-hop culture and music, which was predominantly capitalistic, patriarchal, Eurocentric, heteronormative, and noncritical of social inequality (Dyson 2010; Ogbar 2007; Perry 2004; Rose 2008; Watkins 2005).

In 2012, Macklemore and Ryan Lewis' album The Heist reached critical acclaim as an innovative independent hip-hop album. Receiving national attention, it became a springboard that re-launched the duos' career. In their song "Jimmy Iovine" (2012), who is a music producer and chairman of Interscope Records, Macklemore and Ryan Lewis openly express their dissatisfaction with artists who get tricked into signing with major record labels. They cite problems with creative control, autonomy, and the ability to make profits from their music. Similarly, many independent artists have reflected in their lyrics concerns about the capitalist economy and its influence on the production and distribution of hip-hop music.

Thus, my book addresses an age-old question: To what extent and how independent hip-hop challenges or reproduces US mainstream hiphop culture and US culture more generally in the post-golden era. In particular, I explore and analyze the historical trajectory of independent hip-hop in the post-golden era and how it has affected the culture today. I contend that indie hip-hop remains a complex contemporary subculture. While it consistently expresses grievances related to both race and class inequality, its gender and sexual politics are contradictory. Nonetheless, independent hip-hop expresses the oppositional consciousness of its artists and listeners as well as the limits of that consciousness (Harkness 2012; Kubrin 2005; Lena and Peterson 2008; Martinez 1997; Myer and Kleck 2007; Stapleton 1998). 


\section{OverVIEW of Research}

Harkness (2014) identifies three tiers of hip-hop music. Mainstream hip-hop music is defined as music produced and released by artists who are internationally established and connected to the three major record labels, which own or distribute more than $85 \%$ of the music globally (Universal Music Group, Sony Music Entertainment, and Warner Music Group) (Rose 2008). Conversely, underground hip-hop music broadly refers to any music created outside the commercial canon (Harrison 2006). The underground acts are often not signed to major labels and have not sold over 500,000 albums, but are trying to launch their career in the music industry (Oware 2014). This book focuses on the middle tier of hip-hop music, which is more specifically defined as music created by established independent labels and produced outside the confines of the three major record labels (Vito 2015). These performers are generally locally and regionally successful but operate without the aid of major corporations (Harkness 2014). Additionally, the terms mainstream, underground, and independent are not intended to be dichotomous, static, and reducible to a "set of sine qua non," but rather, a spectrum or continuum that is interrelated, overlapping, emergent, and discursively constructed (Harrison 2009; Terkourafi 2010; Vito 2015). As Oware (2014) points out, many musicians traditionally classified as underground or independent, such as Common or Talib Kweli, are not underground or independent according to the aforementioned criteria.

Independent hip-hop culture, or its values, beliefs, behaviors, and material objects, remains an important tool in the formation of resistance to oppression and domination by the ruling class. Nonetheless, in the USA it remains a severely understudied contemporary subculture (Perry 2004; Terkourafi 2010) despite studies on independent hip-hop that reveal a complex political discourse about the contradictions regarding issues of race, class, and gender within its music (Harkness 2012; Kubrin 2005; Lena 2006; Martinez 1997; Myer and Kleck 2007; Stapleton 1998). My work examines the politics of race, class, gender, and sexuality within independent hip-hop culture, as well as its ability to generate or express oppositional consciousness among its artists and listeners. I seek to build upon the existing scholarship on independent hip-hop (Alridge 2005; Asante 2008; Ball 2009; Bennett 1999a; Harrison 2006; Kitwana 2002; Maher 2005; Ogbar 2007; Smalls 2011) as well as the broader literature on music and culture. 
My central research questions are: To what extent and how does independent hip-hop challenge or reproduce mainstream ideologies, which include ideologies of race, class, gender, and sexuality, within US hiphop culture and US culture more generally? Does independent hip-hop express and inspire among its artists and fans oppositional consciousness, defined as an empowering mental state that prepares members of an oppressed group to undermine, reform, or overthrow a dominant system (Mansbridge and Morris 2001)? How do artists and fans navigate the changing meanings of independent hip-hop culture, particularly in response to changes in technology and media? How do artists' social locations of race, class, gender, and sexuality shape the kinds of messages they produce? How do fans' social locations of race, class, gender, and sexuality relate to their understanding of the messages within independent hip-hop?

My research design utilizes a mixed methods approach. First, I analyze the lyrics of independent hip-hop albums through a content analysis of twentyfive independent albums from 2000 to 2013. I uncover the dominant ideologies of independent hip-hop artists regarding race, class, gender, sexual orientation, and calls for social change. This is unique in that there has not been a comprehensive study of independent albums within the USA over this period of time. By systemically analyzing the content of the lyrics in these post-golden era albums, I uncover the salient grievances of the independent hip-hop community and how they vary across artists to uncover the historical trajectory of independent hip-hop and how it has affected the culture today.

For example, I find that the messages of independent hip-hop artists are vexed and contradictory. Consistent with Balaji (2010), I find that much of independent hip-hop of this genre is largely produced by straight, male, working-class youth of color. Similar to Oware (2014), I also find that while musicians often challenge dominant beliefs about race and class relations, they sometimes reinforce traditional views of gender and sexuality. There are exceptions to such trends, of course. Some artists, namely queer and female ones, do challenge traditional views about gender and sexuality, but they tend not to be the most popular and well-known acts in this time period.

Second, I examine interviews with forty-six members of the independent hip-hop community who are self-defined listeners and active fans. I explore the meanings that they associate with hip-hop culture and how technological changes have altered their understanding of the culture from 2000 to 2013, and whether and how this shapes their engagement with oppositional consciousness. I further examine the complex and 
contradictory cultural politics of independent music in the post-golden era, which includes the fluid and blurry lines between mainstream and indie labels, and how hip-hop challenges or reinforces dominant ideologies about race, class, gender, and sexuality.

Similar to the results from content analysis, I find that while much of the culture elucidates the experiences of heterosexual black and Latino men, it often denigrates or neglects other racial and ethnic minorities, women and lesbian, gay, bisexual, transgender, and queer (LGBTQ) groups. This is likely to both shape and limit the oppositional consciousness that it inspires among its listeners as straight, male, working-class youth of color remain the majority and are provided more privilege in claiming authenticity within independent hip-hop culture. In addition, my findings show that there are fluid and blurry lines between mainstream and indie as many performers attempt to retain economic and creative freedom while still attempting to become economically successful. My findings also reveal that acts remain intensely intertwined with major companies in old and new ways to utilize their marketing and distribution channels. Yet while these contradictions exist, interviews determine if hip-hop fans and listeners gain messages that spur them to oppositional consciousness.

My research aims to address a gap in the literature that has traditionally focused either myopically on mainstream hip-hop (Kelley 1994; Perry 2004; Rose 1994), local underground hip-hop (Ball 2009; Harrison 2006; Wang 2014), or the appropriation of US hip-hop in the global sphere (Androutsopoulos and Scholz 2003; Bennett 1999b; Mitchell 2003). This has left independent hip-hop culture in the USA an understudied topic of research, particularly in regard to artists and listeners of the current generation.

Specifically, scholars fail to systematically study independent hip-hop in the post-golden age and its effects on the culture today. I address this gap in the literature by identifying three key themes found in indie hip-hop albums and interviews with independent hip-hop community listeners. First, I focus specifically on the cultural grievances against mainstream culture and major corporations, as well as their support for an alternative indie movement, that acts express in song lyrics during the post-golden era. Second, I examine the claim that major labels profit at the expense of artists, which include economic and political aspects such as forwards, copyright, artist repertoire, touring, merchandising, and press. In addition, I analyze the argument within musicians' lyrics that independent labels help mitigate economic exploitation and corporate 
control. Third, I explore via interviews how listeners interpret and navigate the changing technological and economic landscape of hip-hop and its influence on mainstream and independent subcultures, particularly in relation to race, class, gender, and sexuality. The book concludes with a chapter on the ramifications of the study, recommendations for readers and the independent hip-hop community, and future research.

\section{Theoretical Framework}

My research combines insights from neo-Marxist, critical race, intersectional feminist, and queer theories. In what follows, I critically review each of these theories as well as Mansbridge and Morris' (2001) concept of oppositional consciousness. I then discuss how these theories have informed my research on hip-hop culture.

\section{Relations of Domination and Culture}

Frankfurt School Marxists, such as Theodor Adorno and Max Horkheimer (1969), focus on how culture and class relations interact, rejecting vulgar Marxist theories which view culture simply as a byproduct of the dominant mode of production. They believe that popular culture produced by the "culture industry" reinforces capitalism through the types of messages that it produces. The culture industry refers to the capitalist and bureaucratic structure that disseminates modern popular culture. Similarly ,Gramsci (1971) argues that the dominant classes maintain control of the proletariat through both physical force (coercion) and consent achieved through the dissemination of hegemonic ideas that suggest elites serve their best interests.

Drawing insights from the Frankfurt School, Shusterman (1992) states that mainstream hip-hop represents an "administered culture" created by the ruling class to reinforce hegemonic ideas and prevent the masses from challenging the status quo. Blair (1993) also states that hiphop artists were not only forced into becoming corporatized but also willingly supported the status quo by reproducing the hegemonic practices of major record labels.

While the Frankfurt School emphasized the importance of culture, they failed to adequately address various social locations. Racial formation and intersectional feminist theory suggest that hegemony is shaped 
by multiple relations of domination. Omi and Winant (1994) argue that race is socially constructed and shaped by cultural, economic, and political factors. Extending Gramsci's insights, they argue that racial domination is reinforced through coercion and consent by the masses. They also suggest that race relations and ideologies change over time in response to the struggle among racial groups.

Intersectional feminist theorists, such as Collins (Collins 2005), highlight the interlocking nature of race, class, and gender relations. According to Collins (2005), one's social location within multiple relations of domination interacts simultaneously to shape one's consciousness and understanding of the world. Additionally, Connell (1995) defines "hegemonic masculinity" as the dominant form of masculinity within the gender hierarchy that keeps minority males and women in positions of subordination. It is essentially a configuration of race, class, and gender that promotes an ideal type of white masculinity and denigrates all races and genders that do not uphold it. Hegemonic masculinity is upheld through the physical embodiment of an ideal masculinity, social dominance of hegemonic males over others, and heterosexual prowess over women in all social life ranging from school, sport, and popular culture (Connell and Messerschmidt 2005).

Further, queer theory and other critical theories of sexuality argue that our society upholds patriarchal heteronormativity, which is based on a male/female dichotomy wherein males are seen as innately superior to women. Heteronormativity subsequently presumes a heterosexual/ homosexual dichotomy wherein heterosexuality is seen as normal and superior. As a result, LGBTQ lives are marginalized socially, culturally, and politically in a myriad of ways. Among LGBTQ groups there remains heterogeneity in their experiences, and thus various versions of queer theory emphasize the need to incorporate the insights of intersectional theory (Hammonds 1994; Ferguson 2004). They argue that intersectional theory is necessary because it elucidates the lack of queer colored images in the media and emphasizes the need to rearticulate queer theory to account for race and class dominance (Cohen 1997). N. Sullivan (2003) highlights the importance of "queering" cultural practices to transform traditionally heterosexual artifacts and performances to include the experiences of non-gender conforming modes of sexuality and subjectivity. 
Hip-hop scholars have similarly argued that the fomentation of resistance to social domination requires addressing multiple relations of domination and subordination (Alridge 2005; R. Sullivan 2003). Alridge (2005) states that hip-hop culture is an important site of racial formation in the USA (Omi and Winant 1994). Hip-hop reinforced the gains of racial and ethnic minorities made through the Civil Rights Movement, but has ultimately been limited by the white hegemonic structure that promotes racist ideologies and the consent of artists adhering to it. In contrast, Adams and Fuller (2006) emphasize the salience of gender in their analysis of the underrepresentation, objectification, and marginalization of women in the industry. Balaji (2010) incorporates an intersectional feminist approach (Collins 2005) to argue that black women in hip-hop are often portrayed by male performers as sexually aggressive and promiscuous, which is in contrast to white women who are often portrayed as sexually revered and sacred. Drawing insights from Connell (1995), scholars highlight the importance of hegemonic masculinity as a tool to subordinate other masculinities, as well as women within hip-hop (Iwamoto 2003). For example, black males in hip-hop are expected to exhibit hyper-masculinity in order to be viewed as legitimate. Conversely, because hegemonic masculinity places white men as superior they can incorporate themselves into the culture as color-blind individuals who are not complicit in reproducing the current unequal racial hierarchy.

Hip-hop scholars, building insights from queer theory, have criticized heterosexism within hip-hop and demonstrated how queer hip-hop has remained at the margins. Queer hip-hop artists have nonetheless challenged the predominant views of homosexuality in mainstream culture (N. Sullivan 2003). Hernandez (2014) highlights queer feminist hip-hop practices that challenge heterosexism by discussing the emancipation of coming out of the closet. In doing so, it can be used as a tool for disenfranchised communities who consume and contribute to the culture, particularly queer communities of color and of the working class (Crenshaw 1991). While the social locations of race and class are salient, Harkness (2012) states that hip-hop is no longer shaped by a monolithic black male culture (Dyson 2010; Rose 1994) but is becoming increasingly heterogeneous (Harkness 2012) and must address multiple social locations which include women and LGBTQ groups as well as other racial and ethnic minorities. 


\section{Oppositional Consciousness and Social Movement Activism}

Mansbridge and Morris (2001) define oppositional consciousness as "an empowering mental state that prepares members of an oppressed group to undermine, reform, or overthrow a dominant system" (4). This occurs when members of a group have been treated as subordinate or deviant, and thus claim an oppositional consciousness that: (1) utilizes their subordinate identity as a positive identification, (2) identifies injustices done to their group, (3) demands changes in society, and (4) sees other members as having a shared interest in rectifying the injustices. Collins (2005) adds that these subordinated identities cannot be analyzed in isolation, but rather through a complex interplay between race, class, gender, and sexuality both individually and through broader social structures. In doing so, oppositional consciousness can foment oppositional cultural resistance and practices that include creating "free spaces," or physical spaces to communicate and share perceptions of their experiences with relatively little interference from the dominant group. It can be used for the elaboration and testing of ideas and conscious creativity by activists drawing on experiences from everyday life. For instance, the Disability Rights Movement was able to create images, slogans, literature, humor, rituals, and other cultural expressions in a free and safe space to build a collective identity drawn from their everyday experiences (Mansbridge and Morris 2001).

Neo-Marxist theorists (Freire 1970; Gramsci 1971) emphasize the importance of intellectuals and artists in the formation of critical thinking and oppositional consciousness. Gramsci (1971) argues that organic intellectuals (which include musicians), or those belonging to the working class, are not firmly bound by the hegemonic order, and thus can openly challenge hegemonic ideas and practices. Freire (1970) similarly argues that intellectuals need to develop a relational knowledge with the masses to help them become self-reflective and engage in critical thinking. When critical thinking and oppositional consciousness are created, Mansbridge and Morris (2001) state that it can help inspire social movement activism to change the current hegemonic social order.

Can independent hip-hop foster critical thinking among its fans about existing relations of domination and ultimately spread oppositional consciousness? Morgan and Bennett (2011) argue that hiphop culture encourages and integrates innovative practices that aid 
in the development of oppositional consciousness regarding issues of race, class, gender and sexuality through artistic expression, knowledge production, social identification, and even political mobilization. In addition, hip-hop cultivates organic intellectuals (Gramsci 1971) who can act as intellectual leaders for the community in which they are embedded (Forman 2000; Morgan and Bennett 2011). Artists can act as organic intellectuals because they are produced by a similar economic, social, cultural, and educational environment and share similar life experiences with the masses. They can engage in critical thinking that challenges dominant culture and help spread oppositional consciousness, while not being controlled by or reproducing dominant ideologies. Finally, Clay (2006) argues that members of the hip-hop community have played an important role in supporting and reinforcing broader social movements such as the Civil Rights Movement and the Occupy Wall Street Movement.

Overall, previous research suggests that hip-hop both reproduces and challenges mainstream culture (Rose 1994), and thus engages in a complex process of negotiation between multiple social locations (Balaji 2010) and the fomentation of oppositional consciousness (Forman 2000; Morgan and Bennett 2011). Yet scholars have not systematically explored independent hip-hop culture, and thus, I add to the current literature and empirically determine if recent independent hip-hop culture reproduces or challenges dominant ideologies that uphold various relations of domination and subordination.

\section{Previous Research on the History of Hip-Hop Culture}

Chang (2005) writes that hip-hop's origins can be traced to a tiny seven-mile circle in the South Bronx. It stems from the vocal and musical expression of culture from African-American, Afro Caribbean, and Latino men in the 1970s. The formation of alternative local identities was represented through rapping, DJing, breakdancing, and graffiti. Rap, which is often used interchangeably with hip-hop music, is rooted in African oral traditions such as boasting, testifying, and signifying (Forman 2010; Oware 2016). Hip-hop's origins were a form of expression that reflected the economic and social hardships as the "throwaways of America's capitalism" (Au 2005; Forman 2000; Morgan and Bennett 2011; Pough 2004; Stapleton 1998). Alridge (2005) additionally argues 
that early hip-hoppers offered a form of social critique against racism that supported the goals of the Civil Rights Movement.

Since its inception, hip-hop has faced the concomitant struggle between maintaining its spontaneity and locality in New York with further commodification and cooptation (Pough 2004). As previously mentioned, on the one hand, the culture has been able to address numerous social issues ranging from the prison industrial complex to political movements involving the Black Panthers and the Young Lords. On the other hand, the rise of new technologies, ranging from cassettes, CD players and burners, the Internet, and social media, has allowed for a much easier flow of information and music production that spurs commodification (Dennis 2006; Harrison 2006). Commodification has helped hip-hop move from the margins to the mainstream music industry based on large conglomerates that homogenize music production, the distribution process, and the means of consumption (Rose 2008).

Hip-hop scholars (Watkins 2005) have attempted to understand its complex, multifaceted, politically conflicting, and consistently debated history. The challenge has been to create a dialogue and vocabulary to bridge the culture in the streets and academia. Presented below are the major areas of debate and contestation in the hip-hop literature.

\section{Politics of Hip-Hop Culture}

Perkins (1996) argues that before 1979, hip-hop remained a key component of the flourishing underground culture in the Bronx and upper Manhattan. Boasted by griots, ciphers, and dance battles hip-hop became a breeding ground for discussion and debate on salient social issues. But post-1979 its popularity garnered attention from the mainstream music industry. As George (2005) finds, independent black music has traditionally been an untapped space for growth by corporate labels. Myer and Kleck (2007) and Johnson (2008) add that historically popular music is driven by indie music. Indie labels were the key in finding what audiences wanted to hear by feeling the "pulse" of the public. Large corporations would then use sophisticated modes of production and distribution to take advantage of consumer tastes in order to make a profit. They ultimately mimic popular independent music until music sales declined, and then move on to the next proven commodity in the indie scene to maintain record sales. 


\section{The Fall of the Golden Era}

In the case of hip-hop, the 1990s became an important decade marked by a distinct shift in the culture. Johnson (2008) believes that in the "Golden Era," from 1979 to the mid-1990s, there was lyrical mastery, innovation in beat production, diversity in style and content, and a subsequent meteoric rise of hip-hop music in the mainstream media (Johnson 2008). Myer and Kleck (2007) argue that the extraction from the underground into the mainstream reached a peak in the postgolden era in the late 1990s where the corporatization of the culture, or the full immersion of corporations in the creation of the music, decreased the diversity and cultural influences of the underground. As Rose (2008) points out, by 199881 million hip-hop records were sold but $70 \%$ of purchases were made by whites in mainstream culture.

Myer and Kleck (2007) find that since its corporatization there has been a decrease in one hit wonders. As corporations invested more and more money in artists and albums, they secured their investments by standardizing music to increase record sales and profits. The model allowed companies to buy out indie labels with little risk to boost record sales. For example, Bad Boy Records was bought out by Sony BMG once they obtained enough capital and parity to contend with larger corporations for record sales. In addition, major companies bought out radio stations and flooded the market with musicians they chose through the "pay for play" system. Ball (2009) finds that the average cost to get a song played on the radio is now up to $\$ 1000$ per song per station. Thus, independent artists have historically had a difficult time getting "spins" on the radio, which pushed them toward signing with major labels to obtain financial support.

Rose (2008) points out that this corporatization had deleterious effects for the hip-hop community. For example, copyright ownership transfers ownership of rights from the artist to the studio to sell, promote, and benefit from those copyrighted materials. Thus, the power of ownership becomes more concentrated in the hands of the few, which is best represented by elite white men. As Myer and Kleck (2007) uncover, white males in the music industries' three major record labels are overrepresented in managerial and ownership positions. Within the industry, scholars have pointed to the infiltration and subsequent ownership of major hip-hop labels by whites dating back to the 1970s with white executives such as Malcolm McLaren, Rick Rubin, and Tom Silverman(Chang 2005; George 2005). This very 
small segment of society occupies multiple positions of power in the music industry. It becomes more salient given that three companies either own or distribute more than $85 \%$ of the music distributed globally (Rose 2008).

\section{Resistance from the Underground}

Since hip-hop's rise in 1979, there have been two dominant themes (Lena 2006, 2013; Lena and Peterson 2008; Tickner 2008). First, "conscious rap" was associated with the representation of experiences from a marginalized, subordinated, and discriminated population and was geared toward building a sense of activism among its constituents rather than reproducing stereotypical racial and economic tropes of mainstream society. In particular, these musicians emphasized the local environment and the hostility from corporate America. Second, "gangster rap" portrayed the same representations of the ghetto but upheld values of consumerism and patriarchy. They also blended "street" credibility with commercial success as a hustler "protagonist."

While these two themes are not mutually exclusive, gangster rap became mostly associated with mainstream hip-hop while conscious rap was predominantly produced in the underground (Oware 2014). Yet the mainstream can encompass both gangster rap and conscious rap, and underground and independent hip-hop can have themes of gangster rap. Harrison (2006) clarifies what is meant by underground, stating that while it encompasses a wide variation of topics, it is the hip-hop community closer to the end of the popularity spectrum where audiences consist largely of friends, family, and other associates. As underground artists gain more notoriety, their fan base extends further outside their circle and they gain access to new processes such as record label formations and documentation of album sales. Performers often face a crossroads in deciding to remain underground, signing with or creating an indie label, or signing with a large corporation.

During the post-golden era, the dominant model used by major corporations was gangster rap. Gangster rap emphasized the nihilistic, macho, and violent side of ghetto life. Ironically, its originating impulse was its disgust with the hypocrisies of mainstream culture. For example, Wells-Wilbon et al. (2010) analyze the life of Tupac Shakur to show his long-standing legacy in popular culture, which was filled with both radical critiques of mainstream culture and the reproduction of dominant cultural depictions of gangsters in urban neighborhoods. Hip-hop 
mirrors the values, violence, and hypocrisy of modern culture and represents some "ugly truths about everything society is and is not" (Taylor and Taylor 2007). Thus, Rose (2008) states that it is vitally important to address issues of cooptation within the mainstream.

Conversely, conscious rap has traditionally thrived in the underground and independent scene. In the post-golden era, underground and independent hip-hop act as a tool to both legitimize the authenticity of mainstream culture by pulling some of its artists and culture, but simultaneously counteracts it by distancing itself away from commercialization (Maher 2005; Rose 2008). Morgan and Bennett (2011) point out commercial hip-hop only represents a fraction of artistic production and performance. In this alternative underground space, there is more room to critically challenge the norms of traditional mainstream hip-hop and distinguish itself from mainstream culture. As Harrison (2006) states, the underground can be united in embracing progressive politics of subcultural inclusion and resisting cooptation by large corporations.

Moreover, Ball (2009) analyzes the importance of other material conditions salient to music creation and production. In order to understand the politics of the culture, scholars must analyze the politics by which underground and independent hip-hop navigates corporatization by major companies. For instance, resistance to major record sales comes from mixtapes that are released through means outside corporate distribution. This includes handing out music in person on the streets, airtime at clubs and independent radio stations, and the spread of music through online Web sites and social networks. Ball looks specifically at FreeMix Radio, which is a freely distributed monthly radio program spread through compact disk and acts as an alternative means of expression free from the filters of mainstream media. Harkness (2012) similarly explores the Chicago underground hip-hop scene by analyzing how it can remove itself from corporate infrastructure through self-production. Maher (2005) also analyzes the importance of self-production with indie rappers Dead Prez and finds that they can act as intellectuals freely speaking on their ghettocentric (i.e., their experiences in urban low-income neighborhoods) and Afrocentric (or experiences revolving around being African-American) experiences.

Scholars (Ogbar 2007; Adams and Fuller 2006) argue that hip-hop negotiates a complex cultural and political landscape in its search to create a sense of identity. It is not monolithic and unitary, but rather diverse and highly dependent upon historical context and the ways in which the 
hip-hop community experience and understand life. This is most salient in the relationship between the mainstream and the independent. For example, Karubian (2009) states that big labels sign fewer acts today and instead focus on signing established independent acts looking to break into the mainstream. Many artists may treat the independent and underground scene as a "waiting station or the minor leagues" until they achieve more popularity and sign lucrative contracts with major labels (Oware 2014). Conversely, some acts such as MF Doom (Hess 2012) began their careers signing with a larger label but have since dropped them to obtain successful careers as indie artists (Oware 2014). In essence, many musicians negotiate terms for mutually beneficial outcomes to generate profits (Ostrove 2014).

Similar to punk rock (Hesmondalgh 1999), independent hip-hop has seen periods of commodification and resistance (Lopes 1992). Suhr's (2011) findings highlight a recent period of commodification in the music industry as major and independent labels have converged despite their consistently changing relations of tension and compatibility. As a result, Oware (2014) contends that we cannot view these two subcultures with reinforced and restricted boundaries, but rather as a fluid continuum by which many musicians and fans continuously define and navigate. Thus scholars (Dyson 2010; Hess 2012 ; Hill 2009; Oware 2014) argue that it is necessary to study both mainstream and independent hip-hop culture and acknowledge the complex and contested site for both resistance and domination.

\section{The Role of Race and Gender in Hip-Hop}

While underground and independent hip-hop can be unified in their attempts to resist corporate domination in the post-golden era, Asante (2008) argues it still has the potential to reproduce racist ideology and unequal gender relations. Scholars (Harkness 2012) have thus focused on the resistance and complicity of the culture along various intersecting axes of domination such as race, class, and gender.

\section{Racial Inequality and the Perpetuation of Racial Stereotypes}

Hip-hop's origins offered a social critique of racism similar to Civil Rights activists. While largely being devoid of a sound intellectual activist foundation, the culture still engaged in resistance to racist policies in the USA and offered a hidden political discourse for African-Americans 
to engage, negotiate, and interpret their identities (Alridge 2005; R. Sullivan 2003).

As hip-hop spread from the margins to the mainstream, AfricanAmerican culture had to negotiate the struggle between remaining directly tied to the experiences of blacks in search of alternatives to white mainstream culture (McCall 1994) and appeasing the broader audience to sustain its growth and record sales (McLeod 2005). Perry (2004) states that hip-hop became a public discourse reflecting both the good and bad of American society through the lens of black America.

In the post-golden era large corporations have manipulated the images of hip-hop to appease a larger audience enthralled with violence and poverty. As R. Sullivan (2003) finds, African-Americans were more likely to state that hip-hop is a reflection of societal reality. But for outside consumers, this gritty portrayal of urban life was highlighted as a "black culture" immersed in crime, violence, drug use, and gang-related activity. Reyna et al. (2009) find that these negative images of blacks were primarily attributed to individual problems of the black community in the USA. Rebollo-Gil and Moras (2012) remind readers that the commodification of black sexuality is a major component in recreating a system of institutionalized racism in America.

As a response, hip-hop has faced critiques from white critics and politicians who blamed it for violence and gang activity in the USA (Rebollo-Gil and Moras 2012). For example, Vice President Dan Quayle attacked Tupac Shakur's lyrics, President G. H. W. Bush criticized Ice-T's image, and President Bill Clinton blamed Sister Souljah for promoting violence. Even notable African-American figures such as Deloris Tucker and Reverend Calvin Butts have criticized hip-hop. R. Sullivan (2003) points out that as hip-hop has become "wider and whiter," messages of antiracism have decreased in favor of messages of gang activity and drug use. Nonetheless the counter-knowledge, or knowledge that challenges dominant ideologies (Gosa 2011; Kelley 1994), produced by performers such as Immortal Technique and Mr. Life still remains and provides opportunities to challenge race relations despite cooptation by major corporations in twenty-first-century America (Williams 2008). Obama's recent administration has allowed performers, particularly millennials (Gosa 2010), to utilize mixtapes and Internet spaces to address issues of race and class in a post-Civil Rights America (Forman 2010). 
What Is "Real" Hip-Hop?

As hip-hop continued to spread, it faced cultural appropriation by nonblacks and non-Latinos who engaged in the culture and attempted to gain entry into it. This raises the issue of authenticity in American hip-hop, as it is necessary for artists to establish credibility and identify boundaries among the broader community (Clark 2013; Hess 2005; McLeod 1999). Harkness (2012) shows that different facets of authenticity (such as being black, male, hard, and from the streets) are enforced and maintain boundaries of realness.

Conversely, women, whites, suburban blacks, and other minorities are often deemed as inauthentic and even "posing." Dimaggio (2010) articulates how other minorities, such as second-generation Arab Americans, Asian-Americans, Cuban Americans, and Indian Americans, have used hip-hop as a form of art to navigate their experiences as minority groups in the USA. Similarly, Fraley (2009) shows that white rappers negotiate and rearticulate whiteness to gain authenticity via alternative means. They must make the claim that artists and fans should not look at race but at rap skills and remaining "true to the game" (Hodgman 2013). Usually, entrance by whites such as Eminem and Esoteric requires reinforcing and exaggerating images of masculinity and working-class background to obtain acceptance among mainstream culture (Fraley 2009; Hodgman 2013; Oware 2014).

The entrance of whites has two primary complications. First, hiphop culture becomes more complex as whites now produce and consume the culture while simultaneously reproducing values of sexism and material wealth (Tickner 2008). White artists entering into the culture strengthens the power of white ownership to dictate the social norms of the hip-hop community and broader society. Also, the entrance of white performers replaces racially coded messages with color-blind ones (Rodriquez 2006). White rappers' claim at participation and subsequent authenticity via "rap skills" engages in color-blind racism by denying the existing of power relations by whites.

\section{Another Claim at Authenticity via Glocalization}

Numerous artists (Harkness 2012) and scholars (Perry 2004) argue that hip-hop is a black form of culture and music. Concordantly, race is treated as a fixed category that acts as the ultimate arbiter of authenticity. This presents a problem for scholars who see the appropriation of hiphop by other racial and ethnic groups in the US underground (Kubrin 
$2005)$; most notably Filipino youth in the Bay area who engage in DJing and dancing (Wang 2014). This viewpoint also presents a problem for a growing body of literature that focuses on the cultural appropriation, via diaspora, into new communities globally while simultaneously focusing on local issues (Bennett 1999a; Mitchell 2000).

Androutsopoulos and Scholz (2003) argue that while hip-hop has moved from the margins to the mainstream, it has become a site of cultural appropriation in which hip-hop music has been used in new social and linguistic environments. Numerous studies have demonstrated that this process has reached every corner of the globe. Dennis (2006) shows through ethnographic research of Choc Quib Town and Voodoo SoulJahs to show how Afro-Colombians have appropriated the culture to rework traditional concepts of race and ethnicity. In particular, he finds that they challenge the superiority of mestizos and bring questions of racism to the epicenter of society. Omoniyi (2006) looks at Nigerian hip-hop song lyrics to find a similar process in which Nigerian musicians utilize hip-hop culture with significant variants such as phonological variation, codeswitching (language changing), cross-referencing, nicknaming, colloquialisms, and reinterpretation. Further, Lin (2006) finds that independent Hong Kong hip-hop performers challenge the capitalist practices of the pop culture music industry and produce music within niche spaces for both cultural survival and innovative cultural production. Other works focus on the importance of the culture in Australia (Maxwell 1994; Morgan and Warren 2011; Warren and Evitt 2010), Europe (Delamont and Stephens 2008; Hesmondhalgh and Melville 2002; Mitchell 2000), and Tanzania (Clark 2013).

Global hip-hop is best explained through the process of glocalization, or the simultaneous interaction between global and local dynamics that takes a double-helix form (Smith 1997; Tickner 2008). This is important because local groups can appropriate the culture to address a wide range of issues ranging from the individual, local, and global (Baker 2005; Bennett 1999a). In essence, global hip-hop is translocal because it represents complex cultural dialogues between local innovations in diverse forms, transcultural interactions outside the USA, and interactions between the USA and local spaces (Morgan and Bennett 2011).

Forman and Neal (2004) point out the persistent theme of authenticity in hip-hop culture. Within the USA, this is complicated as traditionally those who are "real" encompass men of color, while those considered to be "fake" are associated with whites, females, and the 
upper class. Yet with cultural appropriation Harkness (2012) shows that a situated authenticity, wherein outsiders emphasize certain categories and deemphasize those that are fixed, better elucidates how malleable the term authenticity is. As such, the concept of authenticity is socially constructed and consistently contested (McLeod 1999). For example, in the USA a poor white male may be more "authentic" than a Japanese middle-class male, but still less authentic than any black male artist. Outside the USA, the idea of cultural appropriation again brings into question the notion of authenticity (Hesmondhalgh and Melville 2002; Mitchell 1996). As Pennycook (2007) and Tickner (2008) point out, the relocation of hip-hop to other contexts contradicts the traditional notion of "keeping it real" in the USA. Nonetheless, while the process of glocalization has allowed for the destabilization of the term authenticity in regard to race, women of color are still often left in a marginalized and precarious situation (Dennis 2006).

\section{Is It an All-Male World?}

Authenticity is traditionally embodied by black male rappers who engage in hyper-masculinity to establish their dominance over women. The literature analyzing authenticity in hip-hop must address social positions of race, class, gender and the intersections between them (Jeffries 2011). As Iwamoto (2003) shows, Tupac Shakur challenged the current class and racial structure but still embodied the hyper-masculinity of AfricanAmericans in American culture. Iwamoto (2003) cites Tupac's use of the "cool pose," his affirmation of "thug life," and his persona as a "ladies man" to explicate how hip-hop mirrors the larger social structure of patriarchy and sexism. Ironically, due to the complex nature of intersectional theory, Iwamoto also finds that Tupac simultaneously reproduces the objectification of women and creates messages valuing women in society as equals. Alim et al. (2010) ultimately argue that the constructions of blackness and masculinity help performers create and negotiate their identities, but simultaneously may support dominant racial and gender hierarchies within broader society.

While notions of hegemonic masculinity in hip-hop both hurt men who do not fulfill expectations of masculinity and help men maintain a patriarchal structure, women remain in a subordinated and marginalized position wherein their voices are actively silenced (Rebollo-Gil and Moras 2012). Using content analysis, Weitzer and Kubrin (2009) determine that hip-hop reproduces "essential" genders and concordant 
conduct norms of the broader society. They find five gender-related themes: (1) naming/shaming, or songs aimed at degrading women, (2) sexual objectification, or the notion that women are only good for sex, (3) distrust of women, or the suspicion of women who are prone to betray men, (4) legitimating violence, or violent punishment toward women, and (5) prostitution and pimping, or women as subordinates to men who are pimps. Similarly, Tanner-Smith et al. (2006) analyze the content of Radio and Records magazine to determine that women in hip-hop are portrayed as vulnerable, domestic, and subordinate sex objects. Within hip-hop videos from 2007 to 2008, Hunter (2011) finds that performers merge ideals of a successful rap mogul with strip club culture to create a gendered relationship based on sexual transaction.

More specifically, hip-hop serves to support the ideological and social systems that have placed African-American women at the bottom of the social ladder. Compared to white women who are portrayed as sexually empowered and liberated, black women are portrayed as embodying a primitive sexuality (Balaji 2010). African-American rappers also often fit one of the following stereotypes: the queen mother who is the intellectual matriarch, the sistah with attitude who is aggressive and defiant, the fly girl who is hypersexual and independent, or the lesbian. Adams and Fuller (2006) add that African-American women are objectified through stereotypes such as the "Sapphire," an overweight and dark-skinned asexual, or a "Jezebel," a loose sexually aggressive woman. In hip-hop's language, the Jezebel is referred to as the "ho" or the "bitch." These preconceived categories reduce women to objects and expendable beings (Adams and Fuller 2006; Harkness 2012) .

The dialectical nature of hip-hop has had contradicting effects for women in the culture (Adams and Fuller 2006. On one hand, the culture exploits black women's sexuality, denigrates black womanhood, and endangers the lives of young black girls (Pough 2004). On the other hand, it has opened a space for women to determine for themselves the image they want to portray (Balaji 2010; Collins 2005; Emerson 2002), and even use that space to create economic opportunities in the marketplace that challenge hegemony by industry elites and take back their sexuality (Miller-Young 2008; Stapleton 1998; Tanner-Smith et al. 2006). Most notably, an analysis of Brooklyn based female rapper Jean Grae elucidates the ways in which her music interrupts notions of black heteronormative sexuality (Smalls 2011). Gupta-Carlson (2010) similarly highlights how female hip-hop dancers in Seattle use their cultural space 
to create political messages and generate audience responses to call attention to the gendering of hip-hop's spaces.

Further, hip-hop has profound influences regarding religion (Morgan and Bennett 2011) and sexuality (Ogbar 2007). For example, women in the global Muslim hip-hop movement challenge broader stereotypes of Muslim culture and universal misogyny. Also, the LGBTQ movement, which started among early hip-hoppers who supported gay and lesbian movements, has formed a growing following in underground and independent movements aimed at raising awareness and promoting equality for LGBTQ groups in the USA.

\section{Oppositional Consciousness}

Kanye West's lyrics demonstrate hip-hop's ability to simultaneously point out his addiction to money and his resistance to racism. Maher (2007) argues that West's lyrics teeter between uncritical (reflecting the status quo) and critical (challenging the status quo) consciousness, which can be both a source of oppression and liberation. These contradictions are found throughout the culture's history as it engages in both resistance and complicity with relations of domination (Mitchell 1996). Ultimately, hip-hop can create an invaluable tool for creating definitions and conceptualizing terms such as race, class, and gender, as well as transcend these boundaries to create social consciousness, resistance, and even potentially inspire social activism (Ogbar 2007; Martinez 1997).

\section{The Message in the Music and the Formation of Oppositional Consciousness} The dialectical nature of hip-hop allows for artists and listeners to create and interpret meaning from music. These interpretations and meanings can simultaneously promote dominant ideologies and resist them. It is thus important for scholars to elaborate on the importance of performers' messages, the interpretations of the listeners, and the messages and meanings of the music itself.

Artists are in a unique position to have visibility in the hip-hop community through various outlets such as ciphers (or freestyles among groups of rappers), live performances, recorded music, and social media (Newman 2005). They are essentially celebrities of varying degrees whose voices can be heard by the public and concordantly be scrutinized or praised for their messages (Ferris 2007). Because of this visibility, rappers such as Eminem and MF Doom (Hess 2005) are able to 
create hidden transcripts, or encrypted messages understood by the hiphop community, that can act as a form of resistance, or what Stapleton (1998) terms "play-as-resistance." These messages exemplify the multiplicity of language which can both be used both as a tool of resistance and as a means of creating and recreating meaning (Potter 1995).

Hip-hop culture also acts as an important tool for listeners to express and reflect on their lived experience (Sanchez 2010; Tickner 2008). In particular, this is salient for the poor and marginalized youth to express their dissatisfaction with mainstream culture and society. Alim (2007) argues that hip-hop takes on its own language and form of communication that is distinctly different from the current hegemonic sociolinguistic order, or the dominant modes of reading, writing, and speaking. It often takes the form of "real talk" or "straight talk," and can be used by listeners to navigate the social world and act as a means of resisting and combating mainstream ideology and culture.

Finally, hip-hop acts as a means of expression both for individual artists and listeners and collective groups with similar critical observations of society (Au 2005; Jenkins 2011). Once created, it can serve as the impetus for oppositional consciousness (Mansbridge and Morris 2001), which is fueled by discontent among groups who suffer from subordination and also have a shared interest in ending or diminishing their subordination. It can be enabled by an oppositional culture, such as hip-hop, that provides ideas, rituals, and long-standing patterns of interaction that can be refined and developed to maintain and spur oppositional consciousness. Furthermore, it can be led by organic intellectuals (Gramsci 1971) from the community who are directly affected by similar grievances and develop a vested interest in changing the current social order. Within the culture's potential is the power to redefine history, create a sense of community, and form an oppositional consciousness (Decker 1993).

\section{What Can the Message Do for You?}

Hip-hop's potential for oppositional consciousness needs to be fostered through critical thinking. Scholars (Akom 2009; Dimitriadis 2009; Hill 2009 ) thus engage in analyses that understand how the hip-hop community promotes a mental state that encourages critical thinking, identity formation based on their social location, and resistance to domination (Freire 1970).

KRS-ONE advocates for a Critical Hip-Hop (Akom 2009) that calls out practices which create conforming listeners who do not question 
social reality. Instead, he argues that it must provide a foundation for critical learning about issues such as racism, police brutality, incarceration, and poverty. As a medium of expression, it can provide a means of "knowledge building" that is applicable to a specific population that has been marginalized. It can occur in a wide variety of levels ranging from primary texts such as lyric writing with a "pen and paper," secondary texts such as the music on the radio or television, and tertiary texts such as ciphers or spoken word poetry groups (Akom 2009; Au 2005; Gosa 2011; Low 2010).

At the core of critical thinking is the formation of identities based on a shared recognition of an oppressed social position. Leard and Lashua (2006) demonstrate through ethnographic research of listeners the ability of hip-hop to express ideas from a disenfranchised social location through a culture and knowledge outside mainstream society, which has two profound consequences. First, it allows for a collective process in which lyrics provide an alternative outlet for the hip-hop community to effectively express their grievances. Second, urban youth of color use these texts to construct locally validated selves and create a sense of community linked to what it means to be marginalized in the USA and around the world. It is in essence an alternative "lived" curriculum to teach important lessons about how to survive in the world and understand how it works (Dimitriadis 2009; Söderman and Folkestad 2004).

Hill (2009) argues that an effective medium for engaging in alternative methods of critical thinking among working-class students of color at the margins of the educational system occurs when hip-hop is incorporated into the classroom. This is particularly salient for students who: (1) believe that the school system does not understand or accommodate their social position, and (2) believe that the school system has failed them. Hip-hop artists and listeners interpret music and integrate its messages into their everyday lives. Connecting hip-hop to education helps them better navigate the learning process by mediating it with their personal experiences, creating an opportunity to build common bonds and a shared community, and developing an alternative curriculum that better accommodates their needs (Petchauer 2010; Stovall 2006).

\section{Hip-Hop Activism}

Hip-hop's artists and community members have had a long history of political activism in social movements ranging from the Civil Rights Movement in the 1960s to the South African apartheid resistance 
movement in the 1980s (Alridge 2005; Chang 2005). Yet hip-hop itself has also faced less success in their own battles for class and racial equality despite sharing similar desires for social change and ending a long legacy of oppression and domination. This may be attributed to the nature of the culture in which artists and listeners are not trained or inclined to be social activists, but rather are subject to market demands, corporate executives, and acceptance from the public (Maher 2005; George 2005). Nonetheless, Kitwana (2002) argues that hip-hop can spark debate and challenge mainstream thought and cannot be disengaged from political action.

Watkins (2005) writes that hip-hop activism, or addressing social issues both in the hip-hop community and broader social life, draws upon the social experiences and harnesses the energy of disenfranchised populations. Hip-hop activism can range from actions focused on the micro-level, such as posting videos and lyrics on Internet Web sites, to broader macro-level activism such as protests, sit-ins, and rallies. Within hip-hop activism, there are two dialectical processes. First, it can exhibit both push and pull factors upon society (Trapp 2005). It can push political systems and mainstream culture into addressing issues of a subgroup that they previously had been unable to accommodate such as African-American youth. It can also pull actors together from the hiphop community and foment action for social change. For example, rappers rejected the conservative nature of the government wherein Ronald Reagan blamed the poor for their deteriorating values and laziness and instead adopted a critical stance toward the government. Second, the hip-hop community can act as both the mirror and engine of a social movement. Contrasting the works of two prominent musicians, Trapp (2005) shows, through analyses of Queen Latifa's and Tupac Shakur's portrayals of women, that they can reflect reality, while simultaneously influencing social movement participants and leaders in the Civil Rights Movement and the Black and Third Wave Feminist Movement.

Activism in hip-hop is most poignantly seen in the creation of oppositional culture from African-Americans, as well as American Indians and Mexican Americans, who use their own cultural resources to resist oppression under internal colonialism (Mansbridge and Morris 2001). Martinez (1997) shows through content analysis of hip-hop music lyrics how political and gangster rappers in the late 1980s and early 1990s provided key themes of anger and resistance toward a racist and discriminatory society. This resistance culminated in the heralded 1992 
Los Angeles riots that expressed messages of resistance, empowerment, and social critique against a racist police department and legal system. Nielson (2012) claims that while this creates messages of resistance, it also creates further responses of enhanced pervasive surveillance and pressure by police institutions. Clay (2006) similarly finds activism through ethnographic fieldwork within the San Francisco Bay Area's youth of color in their attempts to create youth empowerment and political activism through breakdancing. Globally, Forman (2010) highlights community organizing and civic engagement spreading from USA to cities such as London, Paris, Frankfurt, and Rio de Janeiro. Dedman (2011) also finds social activism among independent UK hip-hop's grime scene through ethnographic fieldwork, which appropriates hip-hop into a subculture of resistance and social activism against mainstream's commodification of culture.

\section{The Future of Hip-Hop?}

Hip-hop's engagement with mainstream media has led to the fall of a golden era to commodification by major corporations. Hip-hop has also been accused of reproducing racial and gender inequality. As McWhorter states, it ultimately holds blacks back and in the end it "creates nothing" (McWhorter 2003). Thus the notion of hip-hop being important in creating social change is still highly contested and is subject to debate. But alternative literature has also explicated how hip-hop can be used to criticize race and gender relations. Other subordinate social groups have also appropriated the culture, such as LGBTQ groups and minority groups outside the USA. Scholars have thus highlighted the ability of hip-hop music to express and foster critical thinking and form an oppositional consciousness, which has the potential to result in social activism and social change (Akom 2009; Dimitriadis 2009; Hill 2009).

\section{Data And Methodology}

The methodology for my research includes a content analysis of independent hip-hop lyrics and semi-structured interviews with selfidentified independent hip-hop listeners and community members. Hill (2009) advocates for a three-pronged approach to understanding hiphop culture: (1) political culture, (2) textual analysis, and (3) audience 
reception. Similarly, Griswold (1987) argues that an analysis of a cultural object addresses artists' creative intentions, the circumstances of time and location underlying its production, the comprehension of the lyrics by both artists and listeners, and an explanation of the interpretation of the lyrics via social groups and communities. Following these approaches, my research considers the sociopolitical context when analyzing the lyrics of performers and how the audience interprets their lyrics. My method is appropriate given a research question that addresses the meanings embedded within artists' lyrics and the meanings received by listeners, as well as the fomentation of independent hip-hop as a potentially oppositional culture.

\section{Content Analysis of Independent Hip-Hop Lyrics}

To examine key themes in independent hip-hop lyrics, I identified a sample of twenty-five albums (412 tracks) that meet the criteria for independent hip-hop albums produced between 2000 and 2013. Each album was produced by US artists and released by a record company not affiliated with the three major record labels. While these albums only analyze a specific point in time, the artists chosen for this study have released albums predominantly on independent record labels and have stated their desire to remain independent from 2000 to 2013. Presented in Table 1.1 are the twenty-five albums chosen for this study.

Independent hip-hop labels are not affiliated with the three major record labels, which are Universal Music Group, Sony Music Entertainment, and Warner Music Group. Yet they require a trademarked name and must be legally filed for business status. The record company must also have obtained a retail merchant's license to legally distribute sellable goods to the public. Once the album meets these criteria, it is ensured that these labels possess no direct financial connection to the "Big Three" record labels at the time of the album's release.

Hip-hop's inception began in the 1970s and shifted into more corporatized models in the mid to late 1990s. Concordant with Kubrin (2005: 367), "the year 2000 represents a turning point in the music industry whereby production values more clearly addressed commercial competition," and thus the salience of an alternative form of creative expression in the production and reproduction of music waned. Thus, my analysis focuses specifically on albums from 2000 to 2013, which has not been systematically studied. 
Table 1.1 List of independent hip-hop albums

1. Aesop Rock-Labor Days (2001, Definitive Jux): 14 tracks

2. Atmosphere-God Loves Ugly (2002, Rhymesayers/Fat Beats): 18 tracks

3. Binary Star-Masters of the Universe (2000, Subterraneous Records): 24 tracks

4. Blackalicious-Blazing Arrow (2002, MCA Records): 17 tracks

5. Blu and Exile-Below the Heavens (2007, Sound in Color): 15 tracks

6. Blue Scholars-The Long March (2005, Massline): 9 tracks

7. Brother Ali-Us (2009, Rhymesayers Group): 16 tracks

8. Cakes the Killa-The Eulogy (2013, Mishka Records): 12 tracks

9. Cunninlynguists-A Piece of Strange (2006, QN5/L.A. Underground): 16 tracks

10. Hieroglyphics-Full Circle (2003, Hieroglyphics Imperium Recordings): 16 tracks

11. Immortal Technique-Revolutionary Vol. 2 (2003, Viper Records): 18 tracks

12. Jean Grae-The Evil Jeanius (2008, Babygrande Records): 10 tracks

13. Jedi Mind Tricks-Violent by Design (2000, Superegular Records): 25 tracks

14. KRS-ONE-Hip-Hop Lives (2007, Koch Records): 18 tracks

15. Macklemore and Ryan Lewis-The Heist (2012, Macklemore LLC-ADA): 15 tracks

16. MadVillain-Madvillainy (2004, Stones Throw): 22 tracks

17. MF Doom-Born Like This (2009, Lex): 17 tracks

18. MURS-3:16 The 9th Edition (2004, Definitive Jux): 10 tracks

19. Mykki Blanco-Bettie Rubble: The Initiation (2013, UNO Records): 8 tracks

20. People Under the Stairs- OST (2002, Om Records): 20 tracks

21. Rapsody-The Idea of Beautiful (2012, Jamla): 16 tracks

22. Sage Francis-Li(f)e (2010, ANTI-/Epitaph): 12 tracks

23. Swollen Members-Monsters in the Closet (2002, Battle Axe): 20 tracks

24. Tech N9ne-Killer (2008, Strange Music): 32 tracks

25 Yonas-The Proven Theory (2011, City of Dreams): 12 tracks

Utilizing this approach to selecting independent albums allows this study to address a glaring gap in the literature. Other studies use comprehensive studies of hip-hop lyrics (Kubrin 2005; Lena 2006; Martinez 1997; Weitzer and Kubrin 2009) but solely focus on mainstream albums that are documented, or tracked by sales, by the Recording Industry Association of America or Billboard. Conversely, determining a sample of independent hip-hop albums considered to be influential in the hip-hop community requires a more nuanced method of identifying albums that meet these criteria since many albums obtain popularity via alternative means such as social media, bootlegging, illegal downloading, and file sharing.

The twenty-five independent hip-hop albums were determined by the number of appearances on Web sites that reflect hip-hop music and their total record sales. First, online Web sites that I am familiar with, 
that have been recommended to me by independent listeners, and that were identified using a Google search were used to identify albums that are considered foundational, well known, and successful among independent hip-hop Web sites. The Web sites identified through a Google search were subject to an inspection to ensure their validity. The Web sites chosen include: www.worldstar.com, www.hiphopdx.com, www. hotnewhiphop.com, www.allhiphop.com, and www.undergroundhiphop. com. Second, a Google search was conducted to find various online lists using phrases such as: "the greatest independent hip-hop albums of all time," "influential independent hip-hop albums of all time," and "classic independent hip-hop albums of all time." These lists were used only if the Web site could be verified as a reliable source representing the hiphop community via daily hits/visits and message boards. The message boards were analyzed to determine if the lists created were well received by public users and additional contributions to the list were used to finalize my sample. Third, newer albums were included in the sample to gain heterogeneity in representation for younger artists, women, LGBTQ members, and other racial minorities. Google searches included: "best new independent hip-hop artists," "best female independent hip-hop artists," "greatest female independent hip-hop artists," "LGBTQ independent hip-hop artists," "queer independent hip-hop artists," and "Latino and Asian independent hip-hop artists." Finally, all albums were re-inspected to ensure that albums chosen: (1) were from hip-hop artists who have remained independent between 2000 to 2013, (2) have documented record sales to determine their popularity and financial success, and (3) appeared most frequently on various lists through the methods mentioned above.

The unit of analysis is bars, which is loosely defined as a line in a rap verse. While Shusterman (1992) argues that it is also important to study beats in addition to lyrics, my research will focus on the content of the lyrics. Therefore, each song was recorded by various lyric Web sites. The primary site chosen for transcribing lyrics is www.genius.com for its popularity among the hip-hop community. I listened to each song, while simultaneously reading the lyrics to ensure accuracy. In instances where the Web site may be inaccurate, the author referred to the alternative sites to verify the correct lyrics. The lyrics were then placed in NVivo, a qualitative program to help store and code the data.

Unlike Oware's (2014) work that analyzes five predetermined categories in the lyrics of underground acts, I use a modified grounded 
theory approach to identify recurrent themes (Charmaz 1983; Lio et al. 2008; Strauss and Corbin 1994). Grounded theory approaches traditionally identify themes from an analysis of the data without reference to categories derived from theory. Like thematic analysis, I used deductive, focused coding techniques (Charmaz and Belgrave 2012) to record bars that are aligned with the theories discussed above in an iterative method of constant comparative analysis. I also paid attention to other possible emergent and recurrent themes that may go beyond the thematic categories derived from my theoretical perspective. Next, the data was re-examined to determine the key themes and subthemes and to identify the relations both within and between them. Bars were re-coded as necessary to address potential issues of double entendres, or meanings only understood within a broader social context. Finally, my analysis was guided by my ethnographic notes from personal experiences at hip-hop shows, music festivals, and other interactions relating to the culture. I was also informed by my examination of various media sources such as YouTube videos, online interviews, and artist/label Web sites. Ultimately, a modified grounded theory approach aims at developing substantial theories of independent hip-hop culture derived from a holistic understanding and interpretation of the data.

Presented in Fig. 1.1 are the major themes uncovered from the twenty-five indie albums chosen for the study.

Themes of independent hip-hop music appeared in 297 bars, which were reanalyzed to determine two major categories: culture and economics. Bars were again reanalyzed to compose subcategories. Three subcategories regarding culture were uncovered: (1) a resistance to major corporations, (2) an emphasis on independence, and (3) the creation of an alternative culture. Three subcategories related to economics were found: (1) economic exploitation, (2) specific forms of economic exploitation such as 360-degree contracts and advances, and (3) economic resistance. The categories were additionally studied in conjunction with the other overlapping themes such as capitalism and economy to provide the basis for Chapters 2 and 3 .

\section{Interviews with Independent Hip-Hop Listeners}

To examine the ways in which independent hip-hop community members and listeners interpret and use hip-hop lyrics, I interviewed forty-six self-identified independent hip-hop listeners and fans within 


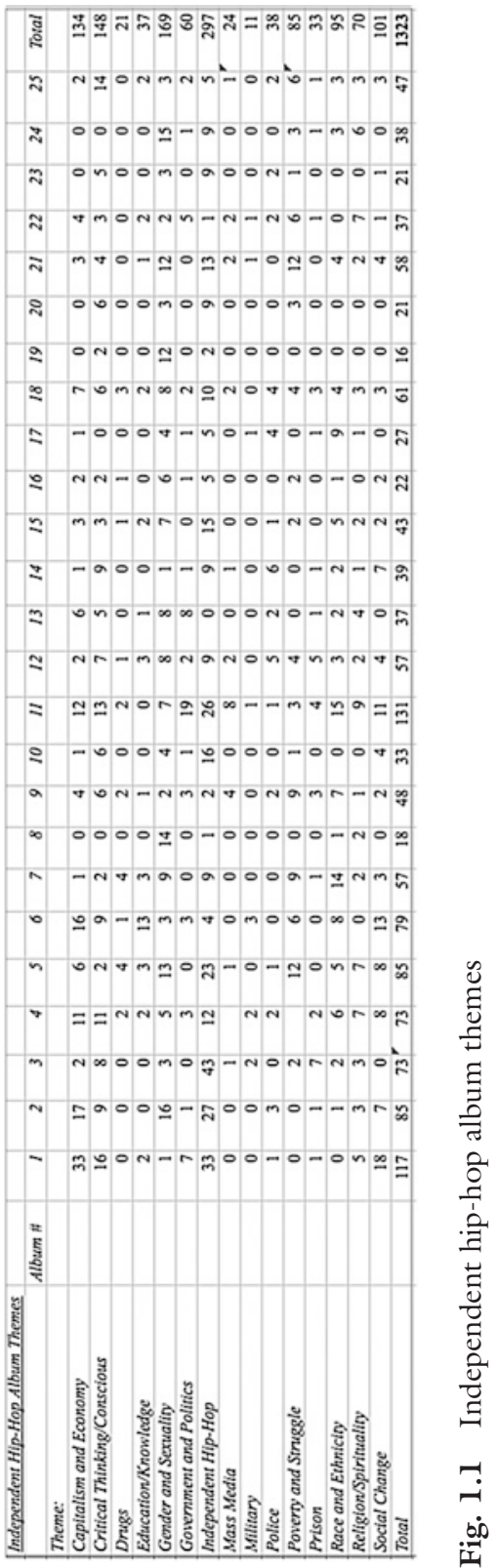


Southern California. The participants were identified through a snowball sample. I recruited from my own personal networks in San Diego, as well as at UC Riverside and San Bernardino Valley Community College to find students who meet the criteria. Open advertisements at college campuses were also given to reach local community members who are familiar with independent hip-hop. Respondents took an initial survey to determine if they qualify for this study given two parameters (see Appendix A): they were insiders who participated in and listened to hip-hop music and also appeared to incorporate hip-hop culture into their lifestyle (Rodriquez 2006). They were first asked to identify their familiarity with independent hip-hop, the artists they listen to, and their activity within the independent hip-hop community. To qualify as informants who are fans of indie hip-hop, respondents must have adequately demonstrated their interest and familiarity with at least ten of the twenty-five independent hip-hop albums identified in the content analysis. They also showed active participation within the hip-hop community through participation in at least five hip-hop related events, which can range from attending concerts, talks by hip-hop artists, or parties where hip-hop music is played within the past three years.

Like previous studies (Jeffries 2011; Rodriquez 2006), I stratified my interview sample in order to make comparisons across various social locations. As described in Appendix B, I have a diverse sample with regard to race/ethnicity, gender, social class, educational attainment, sexual orientation, political orientation, and age. First, I interviewed participants primarily from the following racial/ethnic groups to reflect Southern California's demographics in the hip-hop community: African-American (18\%), Asian-American (28\%), and Latino (46\%). I also conducted interviews with a handful of whites $(4 \%)$ and biracial individuals who were White/Asian and Black/Asian (4\%). Previous reports (Burgess 2012) have argued that whites make up nearly $80 \%$ of hip-hop listeners, but further analysis of the statistic uncovers sampling bias as many albums are not purchased legally, not documented via SoundScan, or do not fall along "mainstream" hip-hop categorizations. Thus, my study interviewed hip-hop listeners from various racial and ethnic backgrounds. Second, I interviewed about equal numbers of men (25) and women (20) within each racial group, with one respondent identifying as gender fluid (1).

Third, I stratified my sample by class using three different indicators: (a) employment status, (b) income, and (c) self-defined social class. A 
majority of respondents reported working full time $(52 \%)$, while some claimed part-time status $(35 \%)$ or being unemployed (13\%). Of those interviewees who stated they were employed an overwhelming majority reported earning less than $\$ 50,000$ a year $(93 \%)$, with only a few respondents earning $\$ 90,000$ or more annually (7\%). Concordantly, a majority of my sample consisted of self-identified working-class individuals $(74 \%)$, with some identifying as middle class (15\%) and upper class $(11 \%)$. Fourth, participants showed to have various educational attainment rates with (11\%) completing high school, (6\%) obtaining an Associate's Degrees, (37\%) currently at a four-year university, (35\%) earning Bachelor's Degree, and (11\%) receiving a Master's Degree. Fourth, my sample aimed to be representative of the US population with regard to sexual identity: (87\%) heterosexual respondents, $(9 \%)$ bisexual respondents, and (4\%) homosexual respondents. Fifth, my sample was skewed in regard to political orientation. Many respondents (48\%) reported not having strong political orientations/affiliations, but suggested that they took various positions based on the issue. Conversely, $(43 \%)$ of interviewees identified as liberal or radical and (9\%) identified as conservative.

Finally, I interviewed hip-hop listeners between the ages of 18-35. Klatch (1999: 72) argues that between the ages of 18-25 (30 respondents) is an important time in the formation of one's political ideology. She claims that high school students are exposed to teachers, books, and school activities that may precipitate critical thinking in the future. I have extended the age limit to 35 to include listeners who were within the age of 18-25 in 2000 (16 respondents) to account for the previous generation of hip-hop listeners. Ultimately, my study explores how people's exposure to independent hip-hop may relate to their social consciousness and political activity.

Despite its small sample size, my research method was appropriate because of its heterogeneous population representative of the diversity among independent hip-hop listeners. An additional strength of my sample was obtaining two San Diego hip-hop artists, one of which created his own label and the other is independent/unsigned. My limitations are twofold: (1) my sample is geographically limited to Southern California residents, and (2) limited to the hip-hop generation associated with baby boomers and millennials born in the 1980s-1990s.

The interviews were conducted in one of two ways. A public space at the respondent's convenience was chosen. They were approximately one 
to two hours in duration and were recorded using an audio device upon verbal agreement. The interview utilized an open-response format, but engaged in questions directly related to the experiences of the listeners with independent hip-hop music, the meanings they obtain from the music, and the concordant actions they engage in or participate in due to the music they listen to. The questions asked were directly related to the salient issues that appeared in the content analysis of the twenty-five independent hip-hop albums. If respondents were not able to meet in person a Skype interview was conducted either via video chat or direct messaging. The same open-response format was used during the one to two hour interview. Attached in Appendix $\mathrm{C}$ is my interview guide. Once completed, the data was coded in NVivo based on the respondents' responses to determine the primary themes presented in the interviews, using the modified grounded theory approach described above. Results presented in Chapter 4 are based on common themes among respondents within the major subtopics on the interview guide in Appendix C: (1) definitions of independent hip-hop, (2) the messages within independent hip-hop music, (3) the politics of independent hip-hop, (4) issues of race, class, and gender, and (5) social change.

Overall, I am well fit for this project as I have been embedded in the culture and have direct ties with the local scene. My content analysis and participant interviews are informed from my long-time experiences as an avid listener and active participant in hip-hop, allowing me to develop a thick, rich, and holistic understanding of the hip-hop community. My position as an "insider" (a fan) enables me to better understand the complexities of the culture. Merton (1972; Simmel and Wolff 1950) states that insiders are in a position to understand the experiences of groups of which they are members, and can be used to gather a richer set of data (Dwyer and Buckle 2009; Kerstetter 2012). Similarly, DeVault (1999) writes that insider status allows for enhanced access and rapport, but more importantly allows for the possibility of active attention and analysis of social locations.

Previous research has used insider status to obtain ethnographic data, ranging from San Francisco's underground hip-hop scene (Dimitriadis 2009) to evening education programs utilizing hip-hop pedagogy in Philadelphia (Hill 2009), that would otherwise be inaccessible to mainstream researchers. As Low (2010) states, hip-hop insiders hold a precarious position of trust within the community, which allows for access 
to information and resources unattainable by outsiders whom they may perceive as inauthentic, ingenuous and ultimately incapable of understanding their social position. My insider status is thus highlighted by my ability to access online materials, new music, concerts, and events, as well as access to initial contacts within the hip-hop community who know and trust me. Finally, the hip-hop community may face scrutiny from outsiders for their beliefs, ideas, and actions. While I consider myself to be an insider as a fan and as man of color from a working-class background, I simultaneously face the problem of being an outsider for some fans as an academic and because of my particular race, gender, and sexual orientation (a Filipino-American heterosexual male). In my research I am attuned to my outsider status and aware of reflexivity regarding race, class, gender, and sexuality.

\section{Overview of Major Findings}

My findings document the claims of independent hip-hop culture from 2000 to 2013 and highlight the vexed and contradictory nature of the politics of independent hip-hop. Chapter 2 aims to uncover how independent hip-hop in the post-golden era challenges or reproduces cultural ideologies within US mainstream hip-hop culture and US culture more generally. Based on my content analysis of artists' lyrics, I identify three recurrent themes among albums by twenty-five independent hip-hop artists. First, these acts resist the majors in three ways: (1) mainstream artists, (2) large radio stations, and (3) major record labels. Second, they reject the corporatization and commodification by major record labels and mainstream culture in favor of independently owned companies. Third, they advocate for an independent culture based on alternative cultural ideals, and thus socially construct and advocate for a brand of authenticity rooted in hip-hop's origins.

Chapter 3 focuses on how independent hip-hop artists in the postgolden era resist economic exploitation from mainstream culture and major corporations in various ways. Indie musicians make the grievance that major labels benefit at the expense of performers and hence are highly exploitative. Their unfair treatment is predominantly reflected in the contracts acts sign with major labels. This has repercussions for artists in numerous facets of the music industry: (1) advances/forwards, (2) control of copyrights, (3) artistic direction and relations with $A \& R$, 
(4) touring, merchandising, and advertising deals, and (5) radio stations, media, and press. Finally, some hip-hop artists make the claim that creating and maintaining independent record labels helps mitigate economic exploitation, controls record label oversight, and serves for the betterment of the hip-hop community.

Chapter 4 utilizes forty-six interviews with self-identified independent hip-hop listeners to navigate the changing meanings of independent hip-hop in the post-golden era. The chapter elaborates on listener's definitions of independent and mainstream hip-hop. It also analyzes their interpretations of race, class, gender, sexual orientation, and the fomentation of oppositional consciousness. Listeners suggest that independent hip-hop often focuses on race and class but often ignores issues of gender and sexuality. Among my informants, I find that female and queer listeners are more conscious of this omission than male and straight listeners, despite a current push toward female and LGBTQ representation in hip-hop's mainstream. Also, interviews indicate that there remains a blurry line between independents and majors that many artists navigate as they attempt to retain economic and creative freedom while still attempting to become financially successful. Technological shifts and advances have further exacerbated these blurry lines. For instance, my findings reveal that artists remain intensely intertwined with major companies in old and new ways to utilize their marketing and distribution channels. In essence, the culture is not viewed as binary oppositions but rather as fluid and constantly changing in the ways that they are complexly intertwined.

Chapter 5 recapitulates the key findings. I also connect my research to broader societal implications and show how my work is salient to the current body of literature. Currently, it fills two large gaps in the literature. Most works tend to focus on mainstream hip-hop (Kelley 1994; Perry 2004; Rose 1994), disparate underground groups (Ball 2009; Harrison 2006; Wang 2014), or global hip-hop (Androutsopoulos and Scholz 2003; Bennett 1999b; Mitchell 2003), leaving a large portion of the culture in the USA understudied. Also, a majority of hip-hop (Kelley 1994; Perry 2004; Rose 1994) focus on "old school" hip-hop culture, leaving a plethora of research uncovered regarding younger artists and listeners in the present. The major implications of my research are threefold: (1) it aims to better understand the politics of independent hip-hop culture through the lens of artists and listeners in the post-golden era, (2) it adds to the current scholarship by giving 
a voice to the new generation in the hip-hop community concerned with issues of race, class, gender, sexuality, and oppositional consciousness, and (3) it understands the complexity and changing nature of the culture. Future research needs to be done to understand the current state of hip-hop and its relationship to the broader community in order to anticipate future directions in society. Artists' and listeners' grievances are changing, especially as independent hip-hop artists and listeners are becoming more diverse in terms of their gender, sexuality, and racial and ethnic makeup, a new generation of artists and listeners is emerging, technological and media changes are shifting the boundaries between independent and major, and the political and economic context is shifting. All of these changes are likely to have important implications for the potential of independent hip-hop to inspire oppositional consciousness among its listeners.

\section{REFERENCES}

Adams, Teri, and Douglas Fuller. 2006. "The Words Have Changed but the Ideology Remains the Same: Misogynistic Lyrics in Rap Music." Journal of Black Studies 36 (6): 938-957.

Adorno, Theodor, and Max Horkheimer. 1969. The Dialectic of Enlightenment. New York: Continuum.

Akom, Antwi. 2009. "Critical Hip Hop Pedagogy as a Form of Liberatory Praxis.” Equity \& Excellence in Education 42 (1): 52-66.

Alim, Samy. 2007. "Critical Hip-Hop Language Pedagogies: Combat, Consciousness and the Cultural Politics of Communication." Journal of Language, Identity of Education 6 (2): 161-176.

Alim, Samy, Jooyoung Lee, and Lauren Mason Carris. 2010. "'Short FriedRice-Eating Chinese MCs' and 'Good-Hair-Havin Uncle Tom Niggas': Performing Race and Ethnicity in Freestyle Rap Battles." Journal of Linguistic Anthropology 20 (1): 116-133.

Alridge, Derrick. 2005. "From Civil Rights to Hip Hop: Toward a Nexus of Ideas." The Journal of African American History 90 (3): 226-252.

Androutsopoulos, Jannis, and Arno Scholz. 2003. "Spaghetti Funk: Appropriations of Hip-Hop Culture and Rap Music in Europe." Popular Music and Society 26 (4): 463-479.

Asante, Molefi Kete. 2008. It's Bigger Than Hip Hop: The Rise of the Post-HipHop Generation. New York: St. Martin's Press.

Au, Wayne. 2005. "Fresh Out of School: Rap Music's Discursive Battle with Education." The Journal of Negro Education 74 (3): 210-220. 
Baker, Geoffrey. 2005. "Hip Hop Revolucion! Nationalizing Rap in Cuba.” Ethnomusicology 49 (3): 368-402.

Balaji, Murali. 2010. "Vixen Resistin': Redefining Black Womanhood in HipHop Music Videos." Journal of Black Studies 4l(1): 5-20.

Ball, Jared. 2009. "FreeMix Radio: The Original Mixtape Radio Show: A Case Study in Mixtape 'Radio' and Emancipatory Journalism." Journal of Black Studies 39 (4): 614-634.

Bennett, Andy. 1999a. "Hip Hop Am Main: The Localization of Rap Music and Hip Hop Culture." Media, Culture \& Society 21 (1): 77-91.

Bennett, Andy. 1999b. "Rappin' on the Tyne: White Hip Hop Culture in Northeast England-An Ethnographic Study." The Sociological Review 47: $1-24$.

Blair, Elizabeth. 1993. "Commercialization of the Rap Music Youth Subculture." In That's the Joint! The Hip-Hop Studies Reader, edited by Murray Forman and Marc Anthony Neal, 493-504. New York: Routledge.

Burgess, Omar. 2012. "Today's Mathematics: How Hip-Hop Measures Commercial Success." Retrieved April 15, 2016. http://hiphopdx.com/ editorials/id.2023/title.todays-mathematics-how-hip-hop-measurescommercial-success.

Chang, Jeff. 2005. Can't Stop Won't Stop: A History of Hip-Hop Generation. New York: St. Martin's Press.

Charmaz, Kathy. 1983. The Grounded Theory Method: An Explication and Interpretation. In Contemporary Field Research: A Collection of Readings, edited by Robert Emerson, 109-126. Boston: Waveland.

Charmaz, Kathy, and Liska Belgrave. 2012. Qualitative Interviewing and Grounded Theory Analysis. In The SAGE Handbook of Interview Research: The Complexity of the Craft, edited by Jaber Gubrium, James Holstein, Amir Marvasti, and Karyn McKinney, 2nd ed., 347-366. Thousand Oaks, CA: Sage.

Clark, Msia Kibona. 2013. "The Struggle for Hip Hop Authenticity and Against Commercialization in Tanzania." The Journal of Pan African Studies 6 (3): $5-21$.

Clay, Andreana. 2006. "All I Need Is One Mic: Mobilizing Youth for Social Change in the Post Civil Rights Era." Social Justice 33 (2): 105-121.

Cohen, Cathy. 1997. "Punks, Bulldaggers, and Queens: The Radical Potential of Queer Politics?" GLQ: A Journal of Lesbian and Gay Studies 3 (4): 437-465.

Collins, Patricia Hill. 2005. Black Sexual Politics: African Americans, Gender, and the New Racism. New York: Routledge.

Connell, Raewyn. 1995. Masculinities. Berkeley: University of California Press.

Connell, Raewyn, and James Messerschmidt. 2005. "Hegemonic Masculinity: Rethinking the Concept." Gender \& Society 19 (6): 829-859. 
Crenshaw, Kimberle. 1991. "Beyond Racism and Misogyny: Black Feminism and 2 Live Crew." Boston Review: A Political and Literary Forum 16 (6): 30-33.

Davey D. 1984. "What Is Hip Hop?" Retrieved January 1, 2018. http://www. daveyd.com/whatishipdav.html.

Decker, Jeffrey Louis. 1993. "The State of Rap: Time and Place in Hip Hop Nationalism." Social Text 34: 53-84.

Dedman, Todd. 2011. "Agency in UK Hip-Hop and Grime Youth Subcultures-Peripherals and Purists." Journal of Youth Studies 14 (5): 507-522.

Delamont, Sara, and Neil Stephens. 2008. "Up on the Roof: The Embodied Habitus of Diasporic Capoeira." Cultural Sociology 2 (1): 57-74.

Dennis, Chrisopher. 2006. "Afro-Columbian Hip-Hop: Globalization, Popular Music and Ethnic Identities." Studies in Latin American Popular Culture 25: 271-295.

DeVault, Marjorie L. 1999. Liberating Method: Feminism and Social Research. Philadelphia: Temple University Press.

Dimaggio, Paul. 2010. Art in the Lives of Immigrant Communities in the United States. New Brunswick, NJ: Rutgers University Press.

Dimitriadis, Greg. 2009. Performing Identity/Performing Culture: Hip Hop as Text, Pedagogy, and Lived Practice. New York: Peter Lang.

Dwyer, Sonya, and Jennifer Buckle. 2009. "The Space Between: On Being an Insider-Outsider in Qualitative Research." International Journal of Qualitative Methods 8: 54-63.

Dyson, Michael Eric. 2010. Know What I Mean: Reflections on Hip-Hop. New York: Basic Civitas.

Emerson, Rana. 2002. "Where My Girls At?: Negotiating Black Womanhood in Music Videos." Gender and Society 16 (1): 115-135.

Ferguson, Roderick. 2004. Aberrations in Black: Toward a Queer of Color Critique. Minneapolis: University of Minnesota Press.

Ferris, Kerry. 2007. “The Sociology of Celebrity." Sociological Compass 1 (1): 371-384.

Forman, Murray. 2000. "Represent: Race, Place, and Space in Rap Music." Popular Music 19 (1): 65-90.

Forman, Murray. 2010. "Conscious Hip-Hop, Change, and the Obama Era." American Studies Journal 54: 1-20.

Forman, Murray, and Marc Anthony Neal. 2004. That's the Joint! The Hip-Hop Studies Reader. New York: Routledge.

Fraley, Todd. 2009. "I Got a Natural Skill...Hip-Hop, Authenticity, and Whiteness." Howard Journal of Communication 20 (1): 37-54.

Freire, Paulo. 1970. Pedagogy of the Oppressed. New York: The Continuum International Publishing Group.

George, Nelson. 2005. Hip-Hop America. New York: Viking. 
Gosa, Travis. 2010. "Not Another Remix: How Obama Became the First Hip-Hop President." Journal of Popular Music Studies 22 (4): $289-415$.

Gosa, Travis. 2011. "Counterknowledge, Racial Paranoia, and the Cultic Milieu: Decoding Hip-Hop Conspiracy Theory." Poetics 39: 187-204.

Gramsci, Antonio. 1971. Selections from the Prison Notebooks. New York: International Publishers.

Griswold, Wendy. 1987. "A Methodological Framework for the Sociology of Culture." Sociological Methodology 17: 1-35.

Gupta-Carlson, Himanee. 2010. "Planet B-Girl: Community Building and Feminism in Hip-Hop." New Political Science 32 (4): 515-529.

Hammonds, Evelynn M. 1994. "Black (W)holes and the Geometry of Black Female Sexuality." Differences 6 (2): 126-145.

Harkness, Geoff. 2012. "True School: Situational Authenticity in Chicago's HipHop Underground." Cultural Sociology 6 (3): 283-298.

Harkness, Geoff. 2014. Chicago Hustle \& Flow: Gangs, Gangsta Rap, and Social Class. Minneapolis: University of Minnesota Press.

Harrison, Anthony Kwame. 2006. "Cheaper than a CD, Plus We Really Mean It: Bay Area Underground Hip Hop Tapes as Subcultural Artefacts." Popular Music 25: 283-301.

Harrison, Anthony Kwame. 2009. Hip Hop Underground: The Integrity and Ethics of Racial Identification. Philadelphia: Temple University Press.

Hernandez, Jillian. 2014. "Carnal Teachings: Raunch Aesthetics as Queer Feminist Pedagogies in Yo! Majesty's Hip-Hop Practice." Women and Performance: A Journal of Feminist Theory 24 (1): 88-106.

Hesmondhalgh, David. 1999. "Indie: The Institutional Politics and Aesthetics of a Popular Music Genre." Cultural Studies 13 (1): 34-61.

Hesmondhalgh, David, and Caspar Melville. 2002. "Urban Breakbeat CultureRepercussions of Hip-Hop in the United Kingdom." In Global Noise: Rap and Hip Hop Outside the USA, edited by Tony Mitchell, 86-110. Middletown, CT: Wesleyan University Press.

Hess, Mickey. 2005. "Metal Faces, Rap Masks: Identity and Resistance in HipHop's Persona Artist." Popular Music and Society 28 (3): 297-311.

Hess, Mickey, 2012. "The Rap Career." In That's the Joint: The Hip Hop Studies Reader, edited by Murray Forman and Marc Anthony Neal, 634-654. New York: Routledge.

Hill, Marc Lamont. 2009. Beats, Rhymes, and Classroom Life: Hip-Hop Pedagogy and the Politics of Identity. New York: Teachers College Press.

Hodgman, Matthew. 2013. "Class, Race, Credibility, and Authenticity Within the Hip-Hop Music Genre." Journal of Sociological Research 4 (2): $402-413$. 
Hunter, Margaret. 2011. "Shake It, Baby, Shake It: Consumption and the New Gender Relation in Hip-Hop.” Sociological Perspectives 54 (1): 15-26.

Iwamoto, Derek. 2003. "Tupac Shakur: Understanding the Identity Formation of Hyper-Masculinity of a Popular Hip-Hop Artist.” Black Scholar 33 (2): 226-252.

Jeffries, Michael. 2011. Thug Life: Race, Gender, and the Meaning of Hip-Hop. Chicago: University of Chicago Press.

Jenkins, Toby. 2011. "A Beautiful Mind: Black Male Intellectual Identity and Hip-Hop Culture.” Journal of Black Studies 42 (8): 1231-1251.

Johnson, Christopher. 2008. "Danceable Capitalism: Hip-Hop's Link to Corporate Space." The Journal of Pan African Studies 2 (4): 80-92.

Karubian, Sara. 2009. "360 Deals: An Industry Reaction to the Devaluation of Recorded Music." Southern California Interdisciplinary Law Journal 18: 395-462.

Kelley, Robin. 1994. Race Rebels: Culture, Politics, and the Black Working Class. New York: Free Press.

Kerstetter, Katie. 2012. "Insider, Outsider, or Somewhere in Between: The Impact of Researchers' Identities on the Community Based Research Process." Journal of Rural Social Sciences 27 (2): 99-117.

Kitwana, Bakari. 2002. The Hip-Hop Generation: Young Blacks and the Crisis in African-American Culture. New York: Basic Civitas.

Klatch, Rebecca. 1999. A Generation Divided: The New Left, the New Right, and the 1960s. Berkeley: University of California Press.

Kubrin, Charis. 2005. "Gangstas, Thugs, and Hustlas: Identity and the Code of the Street in Rap Music.” Social Problems 52 (3): 360-378.

Leard, Diane, and Brett Lashua. 2006. "Popular Media, Critical Pedagogy, and Inner City Youth.” Canadian Journal of Education 29 (1): 244-264.

Lena, Jennifer. 2006. "Social Context and Musical Content of Rap Music, 19791995." Social Forces 85 (1): 479-496.

Lena, Jennifer. 2013. "Authenticity and Independence in Rap Music and Other Genre Communities." In Explorations in Music Sociology: Examining the Role of Music in Social Life, edited by S. Horsfall, J. M. Meij, and M. Probstfield, 232-240. Boulder, CO: Paradigm Publishing.

Lena, Jennifer, and Richard Peterson. 2008. "Classification of Culture: Types and Trajectories of Music Genres." American Sociological Review 73: 697-718.

Lin, Angel. 2006. "Independent Hip-Hop Artists in Hong-Kong: Cultural Capitalism, Youth Subculture Resistance, and Alternative Modes of Cultural Production." Mobile and Popular Culture 1: 1-18.

Lio, Shoon, Scott Melzer, and Ellen Reese. 2008. "Constructing Threat and Appropriating 'Civil Rights': Rhetorical Strategies of Gun Rights and English Only Leaders.” Symbolic Interaction 31 (1): 5-31. 
Lopes, Paul. 1992. "Innovation and Diversity in the Popular Music Industry: 1969-1990." American Sociological Review 57 (1): 56-71.

Low, Bronwen. 2010. "The Tale of the Talent Night Rap: Hip-Hop Culture in Schools and the Challenge of Interpretation." Urban Education 45 (2): 194-220.

Macklemore, and Ryan Lewis. 2012. "Jimmy Iovine." The Heist. Macklemore LLC-ADA.

Maher, George Ciccariello. 2005. "Brechtian Hip-Hop: Didactics and SelfProduction in Post-Gangsta Political Mixtapes." Journal of Black Studies 26 (1): 129-160.

Maher, George Ciccariello. 2007. "A Critique of DuBoisian Reason: Kanye West and the Fruitfulness of Double Consciousness." Journal of Black Studies 39 (3): 371-401.

Mansbridge, Jane, and Aldon Morris. 2001. Oppositional Consciousness: The Subjective Roots of Social Protest. Chicago: University of Chicago Press.

Martinez, Theresa. 1997. "Popular Culture as Oppositional Culture: Rap as Resistance." Sociological Perspectives 40 (2): 265-286.

Maxwell, Ian. 1994. "True to the Music: Authenticity, Articulation and Authorship in Sydney Hip Hop Culture." Social Semiotics 4 (1-2): 117-137.

McCall, Nathan. 1994. Makes Me Wanna Holler: A Young Black Man in America. New York: Vintage Books.

McLeod, Kembrew. 1999. "Authenticity Within Hip-Hop and Other Cultures Threatened with Assimilation." Journal of Communication 49 (4): 134-150.

McLeod, Kembrew. 2005. "MP3s Are Killing Home Taping: The Rise of Internet Distribution and Its Challenge to the Major Label Music Monopoly." Popular Music and Society 28 (4): 521-531.

McWhorter, John. 2003. "How Hip-Hop Holds Blacks Back.” City Journal 13 (3) (Summer): 66-75.

Merton, Robert. 1972. "Insiders and Outsiders: A Chapter on the Sociology of Knowledge." American Journal of Sociology 78: 9-47.

Miller-Young, Mireille. 2008. "Hip-Hop Honeys and Da Hustlaz: Black Sexualities in the New Hip-Hop Pornography: Feminism, Race, Transnational Feminism, Race Transnationalism.” Special Issue. Meridians 8 (1): 261-292.

Mitchell, Tony. 1996. Popular Music and Local Identity: Rock, Pop and Rap in Europe and Oceania. Leicester: Leicester University Press.

Mitchell, Tony. 2000. "Doin' Damage in my Native Language: The Use of "Resistance Vernaculars" in Hip Hop in France, Italy, and Aotearoa/New Zealand." Popular Music and Society 24 (3): 41-54.

Mitchell, Tony. 2003. "Australian Hip-Hop as a Subculture." Youth Studies Australia 22 (2): 40-47. 
Morgan, George, and Andrew Warren. 2011. "Aboriginal Youth, Hip Hop and the Politics of Identification." Ethnic and Racial Studies 34 (6): 925-947.

Morgan, Marcyliena, and Dionne Bennett. 2011. "Hip-Hop \& the Global Imprint of a Black Cultural Form." Dedalus: The Journal of the American Academy of Arts \& Sciences 140 (2): 176-196.

Myer, Letrez, and Christine Kleck. 2007. "From Independent to Corporate: A Political Economic Analysis of Rap Billboard Toppers." Popular Music and Society 30 (2): 137-148.

Newman, Michael. 2005. "Rap as Literacy: A Genre Analysis of Hip-Hop Cyphers." Text 25 (3): 399-436.

Nielson, Erik. 2012. “'Here Come the Cops': Policing the Resistance in Rap Music." International Journal of Cultural Studies 15 (4): 349-363.

Ogbar, Jeffrey. 2007. Hip-Hop Revolution: The Culture and Politics of Rap. Lawrence: University Press of Kansas.

Omi, Michael, and Howard Winant. 1994. Racial Formation in the United States: From the 1960s to the 1990s. New York: Routledge.

Omoniyi, Tope. 2006. "Hip-Hop Through the World Englishes Lens: A Response to Globalization.” World Englishes 25 (2): 195-208.

Ostrove, Geoffrey. 2014. “The Political Economy of Financially Successful Independent Artists." Class, Race and Corporate Power 2 (1): 1-22.

Oware, Matthew. 2014. "(Un)Conscious (Popular) Underground: Restricted Cultural Production and Underground Rap Music.” Poetics 42: 60-81.

Oware, Matthew. 2016. “'We Stick Out Like a Sore Thumb ...': Underground White Rappers' Hegemonic Masculinity and Racial Evasion." Sociology of Race and Ethnicity 2 (3): 372-386.

Pennycook, Alastair. 2007. "Language, Localization, and the Real: Hip-Hop and the Global Spread of Authenticity." Journal of Language, Identity, and Education 6 (2): 101-115.

Perkins, William. 1996. Droppin' Science: Critical Essays on Rap Music and HipHop Culture. Philadelphia: Temple University Press.

Perry, Imani. 2004. Prophets of the Hood: Politics and Poetics in Hip Hop. Durham, NC: Duke University Press.

Petchauer, Emery. 2010. "Sampling Practices and Social Spaces: Exploring a Hip-Hop Approach to Higher Education." Journal of College Student Development 51 (4): 359-372.

Potter, Russell. 1995. Spectacular Vernaculars: Hip-Hop and the Politics of Postmodernism. Albany: State University of New York Press.

Pough, Gwendolyn. 2004. Check It While I Wreck It: Black Womanhood, HipHop Culture, and the Public Sphere. Boston, NH: Northeastern University Press.

Rebollo-Gil, Guillermo, and Amanda Moras. 2012. "Black Women and Black Men in Hip Hop Music: Misogyny, Violence and the Negotiation of (WhiteOwned) Space." The Journal of Popular Culture 45 (1): 118-132. 
Reyna, Christine, Mark Brandt, and Tendayi Viki. 2009. "Blame It on Hip-Hop: Anti-Rap Attitudes as a Proxy for Justice." Group Processes and Intergroup Relations 12 (3): 361-380.

Rodriquez, Jason. 2006. "Color-Blind Ideology and the Cultural Appropriation of Hip-Hop.” Journal of Contemporary Ethnography 35 (6): 645-668.

Rose, Tricia. 1994. Black Noise: Rap Music and Black Culture in Contemporary America. New York: Wesleyan University Press.

Rose, Tricia. 2008. The Hip Hop Wars: What We Talk About When We Talk About Hip Hop-And Why It Matters. New York: Basic Civitas.

Sanchez, Deborah. 2010. "Hip-Hop and a Hybrid Text in a PostSecondary English Class." Journal of Adolescent \& Adult Literacy 53 (6): 478-487.

Shusterman, Richard. 1992. "Challenging Conventions in the Fine Art of Rap." In That's the Joint! The Hip-Hop Studies Reader, edited by Murray Forman and Marc Anthony Neal, 459-480. New York: Routledge.

Simmel, Georg and Kurt Wolff. 1950. The Sociology of George Simmel. New York: Free Press.

Smalls, Shante Paradigm. 2011. "The Rain Comes Down: Jean Grae and Hip Hop Heternonormativity." American Behavioral Scientist 55 (1): 86-95.

Smith, Christopher. 1997. "Method in the Madness: Exploring the Boundaries of Identity in Hip-Hop Performativity, Social Identities." Journal for the Study of Race, Nation and Culture 3 (3): 345-374.

Söderman, Johan, and Goran Folkestad. 2004. "How Hip-Hop Musicians Learn: Strategies in Informal Creative Music Making." Music Education Research 6 (3): 313-326.

Stapleton, Katina. 1998. "From the Margins to Mainstream: The Political Power of Hip-Hop.” Media, Culture \& Society 20: 219-234.

Stovall, David. 2006. "We Can Relate: Hip-Hop Culture, Critical Pedagogy, and the Secondary Classroom." Urban Education 41 (6): 585-602.

Strauss, Anselm, and Juliet Corbin. 1994. "Grounded Theory Methodology: An Overview." In Handbook of Qualitative Research, edited by Norman Denzin and Yvonna Lincoln, 273-285. Thousand Oaks, CA: Sage.

Suhr, Hiesun. 2011. "Understanding the Hegemonic Struggle Between Mainstream vs. Independent Forces: The Music Industry and Musicians in the Age of Social Media." International Journal of Technology, Knowledge and Society 7 (6): 123-136.

Sullivan, Nikki. 2003. A Critical Introduction to Queer Theory. New York: New York Press.

Sullivan, Rachel. 2003. "Rap and Race: It's Got a Nice Beat, but What About the Message?" Journal of Black Studies 33 (5): 605-622.

Tanner-Smith, Emily, Damian Williams, and Denise Nichols. 2006. "Selling Sex to Radio Program Directors: A Content Analysis of Radio and Records Magazine." Sex Roles 54 (9/10): 675-686. 
Taylor, Carl, and Virgil Taylor. 2007. "Hip-Hop Is Now: An Evolving Youth Culture." Reclaiming Children and Youth 15 (4): 210-213.

Terkourafi, Marina. 2010. Languages of Global Hip Hop. London: Continuum International Publishing Group.

Tickner, Arlene. 2008. "Aqui en el Ghetto: Hip-Hop in Colombia, Cuba, and Mexico." Latin American Politics and Society 50 (3): 121-146.

Trapp, Erin. 2005. "The Push and Pull of Hip-Hop: A Social Movement Analysis." American Behavioral Scientist 48 (11): 1482-1495.

Vito, Christopher. 2015. "Who Said Hip-Hop Was Dead?: The Politics of HipHop Culture in Immortal Technique's Lyrics." International Journal of Cultural Studies 18 (4): 395-411.

Wang, Oliver. 2014. Legions of Boom: Filipino American Mobile DJ Crews in the San Francisco Bay Area. Durham, NC: Duke University Press.

Warren, Andrew, and Rob Evitt. 2010. "Indigenous Hip-Hop: Overcoming Marginality, Encountering Constraints." Australian Geographer 41 (1): $141-158$.

Watkins, S. Craig. 2005. Hip Hop Matters: Politics, Pop Culture, and the Struggle for the Soul of a Movement. Boston, MA: Beacon Press.

Weitzer, Ronald, and Charis Kubrin. 2009. "Misogyny in Rap Music: A Content Analysis of Prevalence and Meanings." Men and Masculinities 12 (1): 3-29.

Wells-Wilbon, Rhonda, Nigel Jackson, and Jerome Schiele. 2010. "Lessons from the Maafa: Rethinking the Legacy of Slain Hip-Hop Icon Tupac Amaru Shakur." Journal of Black Studies 40 (4): 504-526.

Williams, Paul. 2008. "Twenty-First-Century Jeremiad: Contemporary Hip-Hop and American Tradition." European Journal of American Culture 27 (2): $111-132$.

Open Access This chapter is distributed under the terms of the Creative Commons Attribution 4.0 International License (http://creativecommons.org/ licenses/by/4.0/), which permits use, duplication, adaptation, distribution and reproduction in any medium or format, as long as you give appropriate credit to the original author(s) and the source, a link is provided to the Creative Commons license and any changes made are indicated.The images or other third party material in this chapter are included in the work's Creative Commons license, unless indicated otherwise in the credit line; if such material is not included in the work's Creative Commons license and the respective action is not permitted by statutory regulation, users will need to obtain permission from the license holder to duplicate, adapt or reproduce the material.

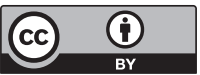

